\title{
DRAGON DANCE OR PANDA TROT? \\ CHINA'S POSITION TOWARDS THE IRANIAN NUCLEAR PROGRAMME AND ITS PERCEPTION OF EU UNILATERAL IRAN SANCTIONS ${ }^{1}$
}

\author{
MORITZ PIEPER ${ }^{2}$
}

\begin{abstract}
In its foreign policy towards the Iranian nuclear programme, China is unwilling to join the partially harsh anti-Iran rhetoric of the US and the EU3. China has averted the imposition of sanctions and only abstained from its veto power as a permanent UNSC member after considerable diplomatic persuasion by 'the West'. Beijing was cautious not to spoil its image as a 'responsible Great Power', walking a diplomatic tightrope in balancing a pragmaticcommercial approach to business in Iran and mollifying Western security concerns related to the Iranian nuclear programme, following the tradition of Deng Xiaoping's doctrine of 'maintaining a low profile'. Increasingly, however, China is conveying a more assertive foreign policy and is no longer hiding its strategic interests. This paper argues that with the EU3 being at the forefront of nuclear diplomacy with Iran, disagreements with China over the EU's recent sanctions policy against Iran can, but need not, be a step in the direction of EU-China strategic alienation in the search for long-term solutions to the Iranian nuclear stalemate.
\end{abstract}

Key words: Iranian nuclear programme; Chinese foreign policy; EU-Iran policy; sanctions

\section{Introduction}

When the European Union (EU) imposed an embargo against Iranian crude oil in 2012, effective as from July the same year, China's reaction was expected with much tension, as the backing of such a punitive diplomacy by a state which has been acting as Iran's de facto protective shield in the United Nations Security Council (UNSC) and which is Iran's biggest oil customer, would have sent a powerful political signal to Tehran. But when Beijing announced that it would not cut back on crude oil imports from Iran and would not join this latest round of Western sanctions over Iran's controversial nuclear programme, the EU stood singled out with its tough line on Iran. China's policy was indicative of its stance in the Iranian nuclear dossier that is marked by an unwillingness to concede to harsh anti-Iran rhetoric on the side of the 'Western' camp of the P $5+1{ }^{3}$ China (together with Russia) has stalled the referral of the Iranian nuclear case from the International Atomic Energy Agency (IAEA) to the UNSC and, within the latter, averted the imposition of sanctions and only abstained from its veto power as permanent UNSC member in the face of growing international concerns over Iran's officially stated peaceful nuclear purposes against the background of considerable diplomatic persuasion

\footnotetext{
${ }^{1}$ Versions of this paper have been presented at the Kent-Ghent doctoral workshop in February 2013 in Brussels and at the UACES 43rd Annual Conference in September 2013 in Leeds. The author thanks the workshop and conference participants as well as the journal's anonymous reviewer for their valuable feedback and input.

${ }^{2}$ Moritz Pieper is a doctoral researcher at the University of Kent's Brussels School of International Studies.

${ }^{3}$ The five permanent UNSC members plus Germany.
} 
and back-door negotiations with the 'Western' negotiators, i.e. the US and the EU3. ${ }^{4}$ China, together with Russia, has traditionally been very critical of UNSC sanctions on Iran, but has followed a policy of navigating its way through support for Iran while also supporting Western positions and exerting pressure on Iran, as evidenced by China's vote for UNSC resolutions 1696 in 2006, 1737 and 1747 in 2007, 1803 in 2008 and, most recently, 1929 in 2010.

It will be the subject of this paper to analyse why China has done so, despite the negative impact on commercial relations with Iran. Against the background of the EU's most recent sanctions in October 2012, imposing, inter alia, an additional ban on Iranian gas imports, asset freezes and travel bans against 'entities active in the oil and gas industry and in the financial sector', this paper will contrast China's foreign policy towards the Iranian nuclear programme with the EU's policy. It will be shown how the growing rift between security political prioritisations between China and the EU negatively affects the EU's leverage to broker policy compromises within the P5+1 and thereby further complicates the search for long-term solutions to the Iranian nuclear stalemate.

A first section will outline China's stakes in Iran as clashing with Western security political concerns regarding Iran's nuclear programme. It will be shown how Sino-American relations in particular had an impact on China's foreign policy towards Iran. A second section will analyse the shift taking place in China's nuclear non-proliferation policies during the 1990s and China's foreign policy towards the Iranian nuclear programme, the existence of which was uncovered in 2002. A final part will, on the basis of the foregoing analysis, contrast China's stance in the Iranian nuclear dossier with the EU's policy and argue how the most recent EU sanctions policies are a step in the direction of strategic alienation against the background of an increasingly assertive Chinese foreign policy. It is China's strategic interest in a stable Middle East, however, that accounts for the potential for long-term resolution of the Iran conflict.

The research method primarily encompasses content analysis of policy documents (primary sources, e.g. declassified documents and press releases), as well as policy briefs and the scholarly literature, supplemented by semi-structured elite interviews and conversations with experts and decision-makers on the basis of non-attribution.

\section{China's Stakes in Iran and Areas of Tension with Western Security Concerns}

Chinese-Iranian relations today are highly determined by the two countries' economic partnership. While China is exporting high-tech capital goods, engineering services and arms to Iran, the latter is primarily exporting oil to China (over 20 per cent of overall Iranian oil exports). ${ }^{6}$ At the same time, China is shipping some of its own refined oil into northern Iran, as

\footnotetext{
${ }^{4}$ In the absence of US-Iranian bilateral relations, it fell to the EU to lead negotiations with Iran as soon as the latter's nuclear programme was uncovered in 2002, with the format of the 'EU3' (i.e. France, Great Britain and Germany plus the EU High Representative for the Union's Common Foreign and Security Policy (CFSP), Javier Solana at the time) quickly becoming the motor of negotiations. EU negotiations with Iran are now coordinated by the EU3 and the European External Action Service (EEAS).

5 'Iran: EU strengthens sanctions over lack of progress in nuclear talks', EU Council Conclusions, available at: http://www.consilium.europa.eu/uedocs/cms Data/docs/pressdata/EN/foraff/132849.pdf (accessed 19 February 2013).

${ }^{6}$ Martin Jacques, When China Rules the World (London: Penguin Books, 2012), p. 435.
} 
Iran - despite its oil wealth - does not have sufficient refining capacities (e.g. oil from the China Petroleum National Corporation-led consortium in Kazakhstan, an economic triangle that ties China, Iran and Kazakhstan together economically). ${ }^{7}$

The importance of oil shipments in Chinese-Iranian economic relations was underlined by a number of major oil deals that have tied the two countries' economies together even more closely, not only cementing Iran's position as one of China's biggest oil suppliers but also making China a key stakeholder and one of the largest investors in the Iranian oil industry. In March 2004, Chinese state oil trader Zhuhai Zhenrong signed a 25-year contract to import 110 million tons of liquefied natural gas (LNG) from Iran worth US\$20 billion. ${ }^{8}$ Likewise, a Memorandum of Understanding (MoU) between China and Iran was signed on 28 October 2004, following which Sinopec (China's second-largest oil company) was allowed to start developing the Yadavaran fields in southern Iran and the ensuing exploration of LNG. China is also now active developing the North Azadegan field in Iran. ${ }^{9}$ Besides these activities, Chinese corporations have invested in non-hydrocarbon sectors: joint ventures have been created; ${ }^{10}$ Chinese companies have been investing in Iranian infrastructure projects; ${ }^{11}$ China's largest steel factory developer is building plants in Yazd province; ${ }^{12}$ and the China International Trust and Investment Corporation (CITIC), together with Chinese Norinco, was contracted for the completion of the Tehran metro system. ${ }^{13}$

Beijing's involvement in the Iranian economy and especially in the oil sector is explained by China's interest in the stability of oil supplies for the Chinese economy. Seen in the context of China's rise as an emerging global power, this need for stable oil supplies becomes a crucial determinant in China's Iran policy. While China's main oil supplier is Saudi Arabia, ${ }^{14}$ Iran comes second. Politically, Saudi Arabia is a more advantageous supplier to China because it still is the US's main ally in the region and a staunch opponent to the idea of Iran developing a nuclear weapon. For China, this rules out the need to reconcile bilateral relations with

\footnotetext{
${ }^{7}$ Dilip Hiro, Inside Central Asia: A Political and Cultural History of Uzbekistan, Turkmenistan, Kazakhstan, Kyrgyzstan, Tajikistan, Turkey, and Iran (New York: Overlook Duckworth, 2009), p. 387.

${ }^{8}$ Dingli Shen, 'Iran's nuclear ambitions test China's wisdom', The Washington Quarterly, Vol. 29 (2006), pp. 5566, p. 61.

${ }^{9}$ Jacques, When China Rules the World, p. 435.

${ }^{10}$ In 2007 and 2008 respectively, a Sino-Iranian joint venture of automobile companies was created (between the Chinese company Chery and the Iranian company Majmoeh Mazi Toos and between Chinese LiFan and the Iranian KMC Company). Cf. International Crisis Group, 'The Iran nuclear issue: the view from Beijing', Asia Briefing, Vol. 100 (2010), p. 7; available at: http://www.crisisgroup.org/ /media/Files/asia/north-eastasia/b100\%20The\%20Iran\%20Nuclear\%20Issue\%20The\%20View\%20from\%20Beijing.pdf (accessed 10 February 2013).

${ }^{11}$ John Calabrese, 'China and Iran: mismatched partners', Jamestown Occasional Papers (2006), p. 9; available at: http://www.jamestown.org/docs/Jamestown-ChinalranMismatch.pdf (accessed 10 February 2013).

${ }^{12}$ Calabrese, 'China and Iran'.

${ }^{13}$ Calabrese, 'China and Iran', pp. 6, 9; 'Iran seeks \$2 bn from China to complete Tehran metro', Tehran Metro; available at: http://tehran-metro.com/featured/iran-seeks-2bn-from-china-to-complete-tehran-metro (accessed 20 February 2013).

${ }^{14}$ In 2011, around 20 per cent of Chinese crude oil imports came from Saudi Arabia, while imports from Iran accounted for 11 per cent of Chinese overall crude oil imports; cf. International Energy Agency, People's Republic of China: Oil and Gas Security. Emergency Responses of IEA Countries (Paris: IEA, 2012), p. 6; available at: http://www.iea.org/publications/freepublications/publication/China_2012.pdf (accessed 12 February 2013).
} 
potentially conflicting Sino-American relations at the same time (as is the case with ChineseIranian relations). US perception of China's foreign policy has remained a crucial factor in Chinese foreign policy since the re-establishing of relations with the US under Nixon and Mao in 1972 and, most recently, since Deng Xiaoping's reform period as from 1978, for the simple reason that US perception of China was crucial for the latter's acceptance to a US-dominated capitalist system that an opening up of Chinese markets comprised. Beijing's desire to portray China as a 'responsible Great Power' (fuzeren de daguo) $)^{15}$ and to convey the image of China's 'peaceful rise' was very much in line with an awareness of not wanting to endanger the US's acceptance of China as an equal power on the world scene. The concept of 'peaceful rise', as introduced in a 2003 White Paper, was even changed to the more harmonious-sounding concept of 'peaceful development' ${ }^{16}$ China's policy consisted of an accommodating approach and a sensitivity to US security interests for the sake of the (temporarily) higher-valued economic development. This latter observation also carries with it a note of caution not to equate the interests of Chinese companies with those of Chinese governments. While China's foreign policy arguably is motivated and informed by economic interests and interest groups, decisionmakers in Beijing have to carefully weigh the pursuance of commercial interests with the perception of China's foreign policy on the part of other major stakeholders. While major investment projects as mentioned above may nurture the impression of extensive ChineseIranian technology transfers, some of these have not yet materialised or remain in the planning phase. This is sometimes the outcome of Chinese strategic behaviour aiming to avoid endangering the 'responsible Great Power' image that a pursuance of commercial contracts in outright disagreement with US security political pressure would entail. The 'extraterritorialisation' of US legislation by way of unilateral sanctions affecting third-country companies serves as another, more material, deterrent. ${ }^{17}$ And, ultimately, the nonmaterialisation of Chinese investment projects in Iran may be the result of political decisions in Tehran - not least because of frustrated perceptions of Chinese receptiveness to US pressure.

It is the effect of Sino-American relations on China's Iran policy that also explains China's voting for UN sanctions resolutions, even though these entail negative effects on Sino-Iranian commercial relations. In this context, John Garver writes of a 'dual game' that China is playing in Iran. ${ }^{18}$ Relations to the US, in a Chinese reading, should not be allowed to wither for the simple fact that China had to accommodate itself with the predominant global superpower, upon whose consent China's entry, recognition and acceptance into the 'international community' depended. By implication, worsening Sino-US relations were often accompanied by improving Sino-Iranian relations, and vice versa. ${ }^{19}$ On a more practical level, the US is militarily present

\footnotetext{
${ }^{15}$ Gerald Chan, Chinese Perspectives on International Relations: A Framework for Analysis (London: Macmillan, 1999), p. 146.

${ }^{16}$ Bonnie S. Glaser and Evan S. Medeiros, 'The changing ecology of foreign policymaking in China: the ascension and demise of the theory of "peaceful rise"', China Quarterly, Vol. 190 (2007), pp. 291-310.

${ }^{17}$ Sascha Lohmann, 'Unilaterale US-Sanktionen gegen Iran' (Unilateral US sanctions against Iran), SWP-Aktuell, Vol. 63 (2013), pp. 1-8.

18 John Garver, 'Is China playing a dual game in Iran?', The Washington Quarterly, Vol. 34 (2011), pp. 75-88.

${ }^{19}$ Lounnas Djallil, 'China and the Iranian nuclear crisis: between ambiguities and interests', European Journal of East Asian Studies, Vol. 10 (2011), pp. 227-53, p. 228.
} 
in the Malacca Strait, through which most of Chinese oil supplies (from Iran) are shipped, ${ }^{20}$ which immediately makes a Sino-US political detune undesirable for China for important logistical reasons.

Another frequently mentioned issue in Sino-US relations and an interesting diplomatic link-up between Sino-US relations and Iran is the Taiwan issue. Bearing in mind China's 'lost territory' and 'One China' rhetoric and the politico-historical importance attached to the 'Taiwan question', ${ }^{21}$ one can comprehend the sensitivity and state of alert with which Chinese governments react to US support to Taiwan. This political importance attached to the Taiwan issue in turn provided the US with leverage over China's support for US foreign policy towards Iran, and vice versa. In September 1992, China for the first time linked its foreign policy towards Iran to the Taiwan question after the US had announced the sale of 150 F-16 fighter aircraft to Taiwan. ${ }^{22}$ And again in 1997, Chinese arms sales to Pakistan and Iran could arguably have been read as a policy of 'retaliation' for the US sale of Stinger anti-aircraft missiles to Taiwan. ${ }^{23}$ At the other end of this competition-cooperation spectrum lies a policy of mutual consent where both parties agree to supply neither Iran nor Taiwan with sensitive technology. In such a case, 'China would agree to sacrifice Iran in return for Taiwan, its greater foreign policy priority. Such a deal would represent a tacit recognition that East Asia was China's sphere of influence and the Middle East, America's'; Martin Jacques sums up such a tit-for-tat strategy and thereby makes an interesting geopolitical link to consents over regional spheres of influence. $^{24}$ This can be read as a dynamic of 'retaliation' in the form of weapons sales to countries of high security and political concern for the respective other and of 'rewarding' cooperation on either side in the form of refraining from such sales if suspension of weapons sales on the respective other side is guaranteed. This nexus underlines once more the importance of US foreign policy as a factor in China's Iran policy to be taken into the equation. A caveat should be attached to the Iran-Taiwan nexus in Beijing's and Washington's respective foreign policy calculations, however. An understanding of an automatic policy of retaliation in arming one side or the other fails to account for more subtle policies that feed into the 'competitioncooperation spectrum' as described above: After the 1996 tensions in the Taiwan Strait and US support for Taiwan, Beijing agreed to suspend its nuclear cooperation with Iran - in spite of continuing arms sales. Support in terms of military hardware is thus not to be equated with unequivocal support for Iran in the diplomacy surrounding the nuclear dossier.

\section{China and Proliferation}

Even though a nuclear-armed Iran would not be in China's interest either, China does not give the same foreign policy priority to nuclear non-proliferation as the US and the EU. China passed on sensitive nuclear technology supplies to Pakistan and Iran in the 1980s and 1990s that were

\footnotetext{
${ }^{20}$ A maritime strait between Indonesia, Malaysia and Singapore, linking the Indian to the Pacific Ocean and the South China Sea. Cf. International Energy Agency, World Oil Choke Points: Analysts' Brief (Paris: IEA, 2012); available at: http://www.eia.gov/countries/regions-topics.cfm?fips=wotc\&trk=p3 (accessed 19 February 2013). ${ }^{21}$ Christopher Hughes, 'Nationalism and multilateralism in Chinese foreign policy: implications for Southeast Asia', The Pacific Review, Vol. 18 (2005), pp. 119-35.

22 Djallil, 'China and the Iranian nuclear crisis', p. 241.

${ }^{23}$ Djallil, 'China and the Iranian nuclear crisis', p. 241.

${ }^{24}$ Jacques, When China Rules the World, p. 436.
} 
at odds with the efforts of the West at the time to consolidate the nuclear non-proliferation regime. Beijing provided a nuclear reactor for the Isfahan Nuclear Technology Centre, signed a memorandum whereby China committed itself to train Iranian scientists and engineers, shared knowledge for the design of nuclear facilities needed for uranium conversion and directly contributed to the building of a uranium conversion facility in Isfahan. ${ }^{25}$ The main controversy concerning Chinese contributions related to Iranian nuclear technology was the sale of natural uranium - a sale that the IAEA did not know of and that was uncovered in 2003 at the Jabr Ibn Hayan Multipurpose Laboratories at the Tehran Nuclear Research Centre. ${ }^{26}$

During the 1990s, China signed up to the relevant treaties and agreements concerning nuclear non-proliferation. Beijing signed the Treaty on the Non-Proliferation of Nuclear Weapons (NPT) in 1992 and the Comprehensive Nuclear-Test-Ban Treaty (CTBT) in 1996. China also joined the Zangger Committee and the Non-Suppliers Group and was supportive of the fissile material reduction treaty. ${ }^{27}$ Thus, economic pragmatism (having supplied Iran with potentially sensitive technology) needed to be carefully balanced against Sino-American relations and China's desire to be perceived as a 'responsible stakeholder' in the field of nuclear nonproliferation in a Western reading.

Faced with the North Korean nuclear crisis, China also proved to be an essential and inevitable state member to the Six-Party Talks over the DPRK's nuclear programme and, in this context, as an important and influential mediator after North Korea had officially withdrawn from the NPT in January 2003 and had expelled all IAEA inspectors from the country. Evolving from a trilateral meeting between North Korean, Chinese and US officials in April 2003, the format for negotiations quickly expanded to the Six-Party Talks by the addition of South Korea, Japan and Russia, with the first round of negotiations being held in Beijing. ${ }^{28}$

As a permanent UNSC member and with this track record of cooperation over North Korea's nuclear programme, China naturally was involved when accusations against the Iranians over their hitherto covert nuclear programme came up at about the same time. Against the background of the precedent analysis of Chinese-Iranian bilateral ties and Chinese-Iranian nuclear technology cooperation, the following section will outline China's foreign policy towards the Iranian nuclear file and Beijing's positioning towards the Iranian nuclear programme from its discovery in 2002.

China's Foreign Policy Towards the Iranian Nuclear Programme as from 2002

\footnotetext{
${ }^{25}$ Djallil, 'China and the Iranian nuclear crisis', p. 236.

${ }^{26}$ Mohamed ElBaradei, The Age of Deception: Nuclear Diplomacy in Treacherous Times (New York: Bloomsburg Publishing, 2011), p. 117.

${ }^{27}$ Nicolo Nourafchan, 'Constructive partner or menacing threat? Analyzing China's role in the Iranian nuclear program', Asian Security, Vol. 6 (2011), pp. 28-50, p. 42; 'Status of signature and ratification', Comprehensive Nuclear-Test-Ban Treaty Organization, available at: $h$ ttp://www.ctbto.org/the-treaty/status-of-signature-andratification/ (accessed 20 January 2013); 'Treaty on the Non-Proliferation of Nuclear Weapons. Status of the treaty', United Nations, available at: http://disarmament.un.org/treaties/t/npt (accessed 20 January 2013). China, however, has not yet ratified the CTBT.

${ }^{28}$ Tae-Hwan Kwak, 'The Six-Party Nuclear Talks: an evaluation and policy recommendations', Pacific Focus, Vol. 19 (2004), pp. 7-55, p. 7f.
} 
At a time when all eyes in the international security and non-proliferation community were on the North Korean nuclear case in 2002, the revelation by an Iranian exile opposition group of the existence of a clandestine Iranian nuclear programme (undeclared to the IAEA and thereby in breach of Iran's NPT Safeguard Agreements) hit the news. ${ }^{29}$ While the EU and US reaction was a harsh condemnation, China's reaction was more reserved: When the EU3, complemented as from late 2003 with the presence of the EU High Representative for the Union's Common Foreign and Security Policy (CFSP), Javier Solana, began to hold talks with the Iranians over their nuclear programme, China underlined the Iranian obligation to prove the exclusively peaceful character of its nuclear programme, but refrained from making assumptions over Iranian intentions that could not be proven. In its official diplomacy, China was thus repeatedly emphasising Iran's legitimate right to peaceful nuclear energy under Article IV of the NPT and was critical of Western rhetoric and pressure on Tehran because of non-proven proliferation concerns. ${ }^{30}$

China was also critical of what it perceived as double standards in nuclear diplomacy, with Iran being harshly criticized for its lack of transparency while the West remained silent on the nuclear activities of non-NPT members such as Israel, Pakistan and India, testifying to what China criticised as 'nuclear favouritism'. ${ }^{31}$ A further Chinese criticism was targeted at the heavy bias towards non-proliferation efforts on the part of the Western nuclear powers, while the unwillingness to effectively engage in nuclear disarmament was uncovered as hypocrisy and a lack of credibility. ${ }^{32}$

After the EU3, together with the mediatory efforts of Javier Solana, had seemingly brokered a deal in 2004 that came to be known as the Paris agreement, in which Iran was asked to suspend uranium enrichment and would in return receive European cooperation in civilian nuclear technology matters, the West suffered a setback when Iran resumed enrichment activities shortly after Mahmoud Ahmadinejad was elected president in August 2005. ${ }^{33}$ Expressing concerns over Iran's lack of cooperation and noncompliance with deadlines set by the Agency, the IAEA then referred the case to the UNSC in February 2006, which adopted resolution 1696 in July of the same year, calling on Iran to suspend uranium enrichment and threatening

\footnotetext{
${ }^{29}$ IAEA, 'Implementation of the NPT safeguards agreement in the Islamic Republic of Iran', IAEA Board report (2003); available at: http://www.iaea.org/Publications/Documents/Board/2003/gov2003-40.pdf (accessed 20 December 2012).

${ }^{30}$ Manochehr Dorraj and Carrier Currier, 'Lubricated with oil: Iran-China relations in a changing world', Middle East Policy, Vol. 15 (2008), pp. 66-80; Garver, 'Is China playing a dual game in Iran?', p. 81f; International Crisis Group, 'The Iran nuclear issue'; Michael Mazza, 'China-Iran ties: assessment and implications for US policy', AEI Iran Tracker (2011); available at: http://www.irantracker.org/analysis/michael-mazza-china-iran-tiesassessment-and-implications-us-policy-april-21-2011 (accessed 11 February 2013); Nourafchan, 'Constructive partner or menacing threat?', p. 39; Michael D. Swaine, 'Beijing's tightrope walk on Iran', China Leadership Monitor, Vol. 33 (2010), pp. 1-19, p. 6f; available at: http://www.hoover.org/publications/china-leadershipmonitor/article/35436 (accessed 11 February 2013); Jing-Dong Yuan, 'China and the Iranian nuclear crisis', Jamestown Foundation: China Brief (2006); available at: http://www.jamestown.org/programs/chinabrief/single/?tx ttnews\%5Btt news\%5D=3926\&tx ttnews\%5Bbac kPid\%5D=196\&no cache=1 (accessed 11 February 2013).

${ }^{31}$ International Crisis Group, 'The Iran nuclear issue', p. 4.

32 International Crisis Group, 'The Iran nuclear issue', p. 5.

${ }^{33}$ Alireza Jafarzadeh, The Iran Threat: President Ahmadinejad and the Coming Nuclear Crisis (New York: Palgrave Macmillan, 2007), p. 159.
} 
sanctions if it didn't. ${ }^{34}$ This was followed by sanctions resolution 1737 restricting technology sales to Iran and imposing first asset freezes, and tightened with resolution 1747 in 2007 imposing further asset freezes and travel bans. In 2008, resolution 1803 was adopted, approving new sanctions for Iran's repeated noncompliance with enrichment suspension and heavy-water related activities. ${ }^{35}$

The latest UN sanctions resolution 1929, adopted in June 2010, toughened the sanctions regime by imposing trade restrictions, targeting banking and transport as well as the energy sector. Travel bans and asset freezes were also imposed against individuals from the Islamic Revolutionary Guards Corps (IRGC), thought to be closely involved in the country's nuclear programme. $^{36}$

Together with Russia, China's approach to sanctions was characterized by the perception of them being a violation of the principle of non-interference and an infringement of Iran's sovereignty. The upholding of the principle of non-intervention and sovereignty is a recurring key Chinese foreign policy concept that has influenced Chinese foreign policy and diplomacy since the 1950s. ${ }^{37}$ In its official positions on the Iranian nuclear issue, China has thus always insisted on political dialogue (as opposed to sanctions) as the only way forward in solving the nuclear crisis. ${ }^{38}$

US and EU sanctions resolution negotiations on Iran were therefore continually delayed by China and the content of the resolutions was significantly watered down by Chinese amendments in what has aptly been described as a 'delay-and-weaken strategy'. ${ }^{39}$ In pursuing this strategy in sanctions negotiations, however, cooperation with Russia was crucial, as China sees 'isolation in the Security Council as something to be strictly avoided'. ${ }^{40}$ Before P5+1 meetings, the Russian and Chinese negotiation teams convened to agree on joint approaches concerning the proposal of amendments of sanctions resolution texts (as did the E3+1, i.e. the

\footnotetext{
${ }^{34}$ ElBaradei, The Age of Deception, p. $191 \mathrm{f}$.

35 UN, 'Security Council demands Iran suspend uranium enrichment by 31 August, or face possible economic, diplomatic sanctions', Resolution 1696 (2006); available at:

http://www.un.org/News/Press/docs/2006/sc8792.doc.htm (accessed 21 December 2012); UN, 'Security Council imposes sanctions on Iran for failure to halt uranium enrichment, unanimously adopting Resolution 1737', Resolution 1737 (2006); available at: http://www.un.org/News/Press/docs//2006/sc8928.doc.htm (accessed 20 December 2012); UN, 'Security Council toughens sanctions against Iran, adds arms embargo, with unanimous adoption of Resolution 1747', Resolution 1747 (2007); available at: http://www.un.org/News/Press/docs/2007/sc8980.doc.htm (accessed 21 December 2012); UN, 'Security Council tightens restriction on Iran's proliferation-sensitive nuclear activities, increases vigilance over Iranian banks, has states inspect cargo', Resolution 1803 (2008); available at:

http://www.un.org/News/Press/docs/2008/sc9268.doc.htm (accessed 21 December 2012); UN, 'Security Council imposes additional sanctions on Iran, voting 12 in favour to 2 against, with 1 abstention', Resolution 1929 (2010); available at: http://www.un.org/News/Press/docs/2010/sc9948.doc.htm (accessed 21 December 2012).

${ }^{36}$ Jafarzadeh, The Iran Threat, p. 145.

${ }^{37} \mathrm{Cf}$. also 'sovereignism': Jonathan Holslag, 'Europe's normative disconnect with the emerging powers', BICCS Asia Paper 5 (2010), pp. 1-21.

${ }^{38}$ Calabrese, 'China and Iran', p. 10; Garver, 'Is China playing a dual game?', p. 81f; Mazza, 'China-Iran ties'; Nourafchan, 'Constructive partner or menacing threat?', p. 39; Swaine, 'Beijing's tightrope walk on Iran', p. 6f; Yuan, 'China and the Iranian nuclear crisis'.

${ }^{39}$ International Crisis Group, 'The Iran nuclear issue', p. 12.

${ }^{40}$ International Crisis Group, 'The Iran nuclear issue', p. 15.
} 
EU3 plus the US, dialogue partners). ${ }^{41}$ In practice, Chinese-Russian joint efforts consistently managed to water down the initial resolution's provisions, with China proposing 'amendments' (in practice, deletion of complete passages) to certain paragraphs, while Russia was proposing amendments to the remaining paragraphs. ${ }^{42}$

While being critical of EU and US pressure on Tehran, China's foreign policy in the Iranian nuclear file is essentially a political tightrope walk: close economic ties with Iran and a perception of sanctions as an interference in the domestic politics of sovereign states on the one hand need to be reconciled with the desire to be perceived as a 'responsible Great Power' that is actively supporting and endorsing nuclear non-proliferation efforts on the other hand. The latter meant a Chinese endorsement of sanctions resolutions against Iran, even though such a policy paradoxically went against Chinese interests, especially against the background of SinoIranian commercial relations.

Another important factor, arguably, was the political momentum at the time of adoption. Even though China has been calling for patience with Iran, political framework conditions made Beijing approve of sanctions when diplomatic soothing strategies would no longer work against the background of major public discontent with Iran. When the international tension and public attention surrounding the Iranian nuclear file was at its height, a Chinese veto would have constituted an outright rejection of Western security political concerns - and international isolation was something Beijing was keen to avoid. This was the case with resolution 1737 in 2006, when Iran had removed IAEA seals from its enrichment facilities in order to re-start uranium enrichment instead of suspending it, as stipulated in the preceding resolution $1696,{ }^{43}$ with resolution 1803 in 2008, when Iran further refused to suspend heavy-water related activities; ${ }^{44}$ and with resolution 1929 in 2010, which was adopted after the revelation of yet another (hitherto unknown) nuclear facility near Qom in autumn 2009. ${ }^{45}$

\section{EU Sanctions against Iran and China's Reaction}

The EU's diplomacy on Iran is characterised by what it has termed - reminiscent of the US 'carrot-and-sticks approach' - the 'dual-track approach'. In close policy coordination with the US, this comprises pressure on Iran, including the imposition of sanctions, ${ }^{46}$ while explicitly

\footnotetext{
${ }^{41}$ German foreign ministry official, conversation with author, 4 February 2013.

${ }^{42}$ German foreign ministry official, conversation with author, 4 February 2013. A comprehensive analysis of joint Chinese-Russian negotiating behaviour is beyond the scope of this paper. Suffice to recall at this point that it would be an analytical fallacy to infer the existence of a united Chinese-Russian 'bloc' confronting the West from such pre-negotiations.

${ }^{43}$ IAEA, 'Implementation of the NPT safeguards agreement in the Islamic Republic of Iran', IAEA Board report (2006); available at: http://www.iaea.org/Publications/Documents/Board/2006/gov2006-53.pdf (accessed 20 December 2012); UN, 'Security Council imposes sanctions on Iran for failure to halt uranium enrichment, unanimously adopting Resolution 1737', Resolution 1737 (2006); available at: http://www.un.org/News/Press/docs//2006/sc8928.doc.htm (accessed 21 December 2012).

${ }^{44}$ UN, 'Security Council tightens restriction on Iran's proliferation-sensitive nuclear activities, increases vigilance over Iranian banks, has states inspect cargo', Resolution 1803 (2008); available at: http://www.un.org/News/Press/docs/2008/sc9268.doc.htm (accessed 21 December 2012).

${ }^{45}$ UN, 'Security Council imposes additional sanctions on Iran, voting 12 in favour to 2 against, with 1 abstention', Resolution 1929 (2010); available at: http://www.un.org/News/Press/docs/2010/sc9948.doc.htm (accessed 21 December 2012).

${ }^{46}$ I.e. EU sanctions in addition to already existing UN sanctions.
} 
stating a readiness to negotiate in case Iran is willing to demonstrate transparency and a willingness to 'work towards clarification of all outstanding issues, including with respect to the possible military dimension to Iran's nuclear programme' ${ }^{47}$ The EU repeatedly stresses its 'serious and deepening concerns' over the Iranian nuclear programme and calls on Iran to 'comply with its international obligations, including full implementation ... of UNSC and IAEA Board of Governors' Resolutions'. ${ }^{48}$ The unwillingness of Iran to allow IAEA inspections at the installations in Parchin and Fordow, where the EU suspects potential military nuclear tests, has been in the spotlight most recently in this regard.

Frustrated with dragging negotiations since 2002 and with the aim of coercing Iran into compliance, the EU has therefore gradually stepped up sanctions in order to dry up the financial sources of Iran's nuclear programme. Starting as a negotiating party and mediator 10 years ago, the EU has steadily leaned further towards the sanctions approach. This now includes restrictive measures in the banking, trade, energy and transport sectors. Assets of individuals involved in activities related to Iran's nuclear programme as well as its ballistic missile programme have been frozen and travel bans imposed. Most prominently, the EU's decision to impose an embargo against Iranian crude oil, taking effect as from 1 July 2012, has attracted international attention and can be said to have been the most assertive and punitive round of EU sanctions imposed so far. ${ }^{49}$ Arguably, it was also a landmark decision for the future direction of EUChinese coordination within the P5+1: After the EU's oil embargo decision, China had made it clear that it would not follow suit and would not impose an embargo against Iranian crude oil imports. However, it did not want to be seen as completely ignoring Western pressure on Iran either. Immediately, China held talks in Qatar, potentially to explore 'swing' exporter states possibilities. ${ }^{50}$ This careful balancing policy again stood indicative of a Chinese need to mollify Western security political concerns. Such a desire, however, does not mean unconditional support for pressure on Iran to an extent to which it significantly impinges upon China's energy and trade relations. All the same, as Saudi Arabia is a more important oil supplier to China, Beijing shows receptiveness to US demands to decrease its purchases of Iranian oil. ${ }^{51}$ Such a policy serves both to respond to US perceptions of China's Iran policies and to qualify for the US presidential 'waivers' in place for those countries that have 'significantly reduced' their import of Iranian oil. ${ }^{52}$

Interestingly enough, acknowledging precisely this conundrum, the US has been encouraging Arab oil exporters 'to boost oil exports to China in an attempt to decrease reliance on Iranian

\footnotetext{
47 'Iran: EU strengthens sanctions'.

48 'Iran: EU strengthens sanctions'.

${ }^{49}$ The Iran oil embargo decision has even been described as an 'ice-breaker for the EU', lowering 'the resistance to further sanctions decisions'. Cf. Stefan Lehne, 'The role of sanctions in EU foreign policy', Carnegie Article (2012); available at: http://carnegieendowment.org/2012/12/14/role-of-sanctions-in-eu-foreignpolicy/etnv (accessed 17 March 2013).

50 'China, Qatar agree to establish petrochemicals JV in China: $\mathrm{Wu}$ ', Chinamining.org; available at: http://www.chinamining.org/News/2012-01-19/1326936959d53586.html (accessed 15 February 2013).

${ }^{51}$ Osamu Tsukimori and Manash Goswami, 'Exclusive: Iran oil exports to plunge, no dividend yet from easing tensions', Reuters (2013); available at: http://www.reuters.com/article/2013/10/25/us-iran-oil-asia-exclusiveidUSBRE9900GF20131025 (accessed 11 November 2013).

52 Lohmann, 'Unilaterale US-Sanktionen gegen Iran', p. 4.
} 
oil and secure agreement to sanctions' ${ }^{53}$ While China was hesitant to accept such deals that would indirectly entail a dependence on the US (acceptance of a US-brokered deal), Beijing nevertheless accepted a boost of oil imports from the United Arab Emirates (UAE) in late $2009 .^{54}$

Beijing's oil trade with Iran should thus not be overestimated as a geostrategic given. Quite pragmatic material interests (qualifying for the US oil trade 'waivers') and identity factors (upholding the image as a constructive dialogue partner) prevent China from importing amounts of oil that would blatantly undermine US efforts to decrease Iranian revenues from its oil trade. However, China was not distressed by the EU's policy of non-insurance of non-EU oil tanker shipments: China let it be known that it would start issuing its own insurance for its oil tanker shipments (as Japan is already doing) after the EU's latest sanctions round entailed a prohibition for EU insurance companies to insure non-EU tankers and cargo vessels against collisions and oil spills. ${ }^{55}$

And with the most recent round of EU sanctions, adopted on 15 October 2012, the EU additionally imposed an embargo against Iranian natural gas and further restrictive measures against the Iranian central bank, widened the export ban to Iran of material that could be used in Iran's ballistic and nuclear programme (such as aluminium and steel as well as related software and technical assistance) and imposed further asset freezes and travel bans for entities and individuals involved in the Iranian nuclear programme. ${ }^{56}$

The Chinese official reaction was unequivocal. 'We oppose the imposition of unilateral sanctions on Iran and believe that using sanctions to exert pressure cannot fundamentally resolve the Iran nuclear issue,' Chinese Foreign Ministry spokesman Hong Lei underlined. ${ }^{57}$ Once more, diverging conceptions on how to approach the Iranian nuclear case had become apparent. While the EU's policy aimed at coercing Iran back to the negotiating table, China was calling on all parties to show 'flexibility, increase communication and push for a new round of talks as soon as possible'. ${ }^{8}$

After the P5+1 negotiations with Iran that took place in Almaty in February 2013, all sides acknowledged that this round of talks had been more successful than the previous ones, with then Iranian Foreign Minister Salehi even describing them as a 'turning point' in the course of nuclear negotiations. ${ }^{59}$ While the Iranian reaction was more outspoken in its optimism about

\footnotetext{
53 International Crisis Group, 'The Iran nuclear issue', p. 14.

${ }^{54}$ International Crisis Group, 'The Iran nuclear issue', p. 14.

55 'EU oil embargo on Iran comes into effect; Tehran says will "confront” sanctions', Alarabiya News; available at: http://www.alarabiya.net/articles/2012/07/01/223821.html (accessed 24 February 2013).

56 'Iran: EU strengthens sanctions'.

57 'China criticizes new EU sanctions on Iran, calls for talks', Reuters; available at: http://www.reuters.com/article/2012/10/16/us-iran-nuclear-eu-china-idUSBRE89F0BF20121016 (accessed 14 February 2013).

58 'China criticizes new EU sanctions on Iran'.

59 'P5+1 had a more realistic approach in Iran talks in Almaty: envoy', Press TV; available at: http://www.presstv.ir/detail/2013/03/09/292657/p51-was-more-realistic-in-almaty-talks/(accessed 14 February 2013); 'Statement by the EU High Representative Catherine Ashton following the E3+3 talks with Iran, Almaty, 27 February 2013', press statement; available at:

http://www.consilium.europa.eu/uedocs/cms Data/docs/pressdata/EN/foraff/135714.pdf (accessed 14
} 
the West moving closer towards the Iranian position, the EU reaction was more reserved. '[T]he real optimism will come when we start to see progress really being made', Catherine Ashton's press statement reads. Part of the reserved EU reaction could arguably be attributed to a substantially modified Western negotiating position, which included, inter alia, the prospect of the gradual lifting of certain sanctions in return for Iran's suspension of uranium enrichment to the 20 per cent level. ${ }^{60}$ After the Almaty talks in early 2013, nuclear negotiations had been paused over the summer as all sides were awaiting the outcome of the Iranian presidential elections in June 2013. The election of Hassan Feridon-Rouhani and the subsequent appointment of Mohammad Javad Zarif as foreign minister has been read as an encouraging signal for renewed negotiations in good faith and potential for constructive diplomacy. ${ }^{61}$ Rouhani seems to have the mandate to steer Iran out of its international isolation, as illustrated by statements coming from Supreme Leader Khamenei about a necessary 'heroic flexibility' ${ }^{62}$ The shift of positions and unprecedented Iranian diplomatic outreach in the fall of 2013 were therefore received with cautious optimism. It should have become clear to all parties involved that insistence on previous positions, which had ultimately led to the failure of talks in 2012, cannot lead to an agreement acceptable to either the West or Iran.

The following and final section will reflect on the extent to which policy divergences over Iran as analysed above, especially concerning the sanctions regime, coincide with an increasingly assertive Chinese foreign policy that breathes the ambition to represent counter-hegemonic alternatives.

\section{Chinese Foreign Policy Assertiveness and the Iranian Nuclear Case - Contesting Modernity?}

China's position towards the Iranian nuclear programme bespeaks a diplomatic tightrope walk in which Chinese governments had to 'triangulate their various interests with Washington and Tehran' without wanting to choose between the two. ${ }^{63}$ Beijing knows its voting pattern on the Iran case in the UNSC is a positioning with far-reaching political implications one way or the other. Voting for UNSC resolutions imposing sanctions on Iran runs against Chinese interests in Iran, while voting against them alienates the US and the EU pushing for a tougher stance towards Iran. Abstaining from a vote might be a way for China to circumnavigate this dilemma,

February 2013); 'Iran-P5+1 talks heading in right direction: Iranian FM', Press TV, available at: http://www.presstv.ir/detail/2013/03/05/291973/iranp51-talks-on-right-track-salehi/(accessed 14 February 2013).

60 'Iran and P5+1: outlook of 2nd meeting in Almaty', Iran Review; available at:

http://www.iranreview.org/content/Documents/Iran-and-P5-1-Outlook-of-2nd-Meeting-in-Almaty.htm (accessed 14 February 2013).

${ }^{61} \mathrm{Cf}$. also Elena Aoun and Thierry Kellner, 'Vers une solution négociée du nucléaire iranien? Dynamiques favorables et vents contraires', note du GRIP (Groupe de recherche et d'information sur la Paix et la Sécurité, 2013), available at: http://www.grip.org/fr/node/1128 (accessed 11 November 2013); Walter Posch and Oliver Meier, 'Bewegung im Nuklearstreit mit dem Iran' (Movement in the nuclear dispute with Iran), SWP-Aktuell, Vol. 62 (2013), pp. 1-8.

${ }^{62}$ Arash Karami, 'Ayatollah Khamenei's "heroic flexibility"', Iran Pulse, available at: http://iranpulse.almonitor.com/index.php/2013/09/2854/khameneis-heroic-flexibilty/ (accessed 11 November 2013); Suzanne Maloney, 'The Rouhani tsunami: a presidential phone call offers another Iranian surprise', Brookings, available at: http://www.brookings.edu/blogs/iran-at-saban/posts/2013/09/27-iran-us-make-history-rouhaniunga?utm source=Facebook\&utm medium=Social\&utm campaign=BrookingsFB0929\&utm content=Brooking sFB0929 (accessed 11 November 2013).

${ }^{63}$ Dingli Shen, 'Iran's nuclear ambitions', p. 63. 
but does not do justice to Chinese claims to being seen as an influential power taking responsibility on issues of global security. As analysed in the previous section, China's attempt to walk the tightrope between pursuing economic interests in Iran and aligning with international efforts to diminish Iranian revenues from its oil trade (thus also evading punitive measures under the US unilateral sanctions regime) is an expression of Beijing's awareness to reconcile these two opposite positions in what effectively constitutes a strategic hedge.

The burgeoning body of literature debating the future direction that Chinese foreign policy might take (revisionist vs status quo power/'cuddly panda' vs 'menacing dragon' debate) ${ }^{64}$ indicates that there is considerable uncertainty in Western circles on the future role and behaviour of a rising and increasingly assertive China: either China continues along the path of socialisation with other global players, works within the existing rules of the game and arrays itself with the global political, economic and monetary system that essentially is based on the post-1945 US-dominated liberal order; or it will seek to use its growing political weight to influence the global order by gradually enforcing its own ideas of managing not only the international economy but global governance at large. It is in this context of power transition that the debate about a shift from the 'Washington consensus' to a 'Beijing consensus' is to be situated. ${ }^{65}$

Undoubtedly, China's foreign policy has become more assertive and independent as China has risen as a global power. With this shift and the subsequent growing importance of China as a foreign political actor on the world scene, the rhetoric in China's foreign policy is starting to change as well. While Deng Xiaoping had outlined a pragmatic doctrine that should accompany China's modernisation process as from 1978 ('hide our capabilities and bide our time; be good at maintaining a low profile; and never claim leadership'), ${ }^{66}$ China's contemporary foreign policy inevitably has to address the country's rise in importance and has been analysed as being

\footnotetext{
${ }^{64}$ Chan, Chinese Perspectives; Steve Chan, 'Can't get no satisfaction? The recognition of revisionist states', International Relations of the Asia-Pacific, Vol. 4 (2004), pp. 207-38; Gregory Chin and Ramesh Thakur, 'Will China change the rules of global order?', The Washington Quarterly, Vol. 3 (2010), pp. 119-38; Yong Deng, 'Reputation and the security dilemma: China reacts to the China threat theory', in Alastair Johnston and Robert Ross (eds), New Directions in the Study of China's Foreign Policy (Stanford, CA: Stanford University Press, 2006), pp. 186-214; Gustaaf Geeraerts and Jonathan Holslag, 'The "pandragon". China's dual diplomatic identity', BICCS Asia Paper 2 (2007), pp. 1-15; Kai He and Huiyun Feng, 'If not soft balancing, then what? Reconsidering soft balancing and US policy toward China', Security Studies, Vol. 17 (2008), pp. 363-95; John G. Ikenberry, 'The future of the liberal world order', Foreign Affairs, Vol. 90 (2011), pp. 56-68; Alastair lan Johnston, 'Is China a status quo power?', International Security, Vol. 27 (2003), pp. 5-56; Alastair lan Johnston, 'Beijing's security behavior in the Asia-Pacific: is China a dissatisfied power?', in J.J. Suh, Peter J. Katzenstein and Allen Carlson (eds), Rethinking Security in East Asia: Identity, Power, and Efficiency (Stanford, CA: Stanford University Press, 2004), pp. 34-96; Henry A. Kissinger, On China (New York: Penguin, 2011), p. 487f; Wei Liang, 'China: globalization and the emergence of a new status quo power?', Asian Perspective, Vol. 31 (2007), pp. 125-49; Jisi Wang, 'China's search for a grand strategy', Foreign Affairs, Vol. 90 (2011), pp. 68-79; Suisheng Zhao, 'China's pragmatic nationalism: is it manageable?', The Washington Quarterly, Vol. 29 (2006), pp. 13144. In this context, cf. also the 'power transition theory': Jack S. Levy, 'Power transition theory and the rise of China', in Robert S. Ross and Feng Zhu (eds), China's Ascent: Power, Security, and the Future of International Politics (Ithaca, NY: Cornell University Press, 2008), pp. 11-33. Zhu Liqun's study, China's Foreign Policy Debates, Chaillot Papers (Paris: European Union Institute for Security Studies, 2010), offers an effective overview of these and other major debates on China's foreign policy.

${ }^{65}$ Shaun Breslin, 'Understanding China's regional rise: interpretations, identities and implications', International Affairs, Vol. 85 (2009), pp. 817-35, p. 827.

${ }^{66}$ Jacques, When China Rules the World, p. 590.
} 
increasingly more assertive. ${ }^{67}$ The stepping-up of the Chinese military, ${ }^{68}$ self-confident maritime moves in the South China Sea ${ }^{69}$ and an uncompromising criticism of the EU's sanctions policy against Iran are cases in point.

From this perspective, China's rise has not only ushered in the end of multipolarity in Southeast Asia ${ }^{70}$ but is the harbinger of an alternative model of global governance at large, at least of the end of the hitherto Western-dominated governance structure. The world would experience what Martin Jacques terms an era of 'contested modernity'. ${ }^{71}$ A perceived growing Chinese new foreign policy assertiveness seems to support the latter reading. While previously China was abiding by Deng Xiaoping's foreign policy doctrine of 'keeping a low profile', it is becoming more outspoken in its foreign policy and is no longer hiding its strategic interests. With a view to Iran and as seen in China's reaction to the EU's latest sanctions round, this means that China does not unquestioningly abide by a strict anti-Iran policy as promoted by other negotiating powers in the Iran dossier. And Western sanctions on Iran even mean an opening up of the Iranian market for Chinese companies: China makes use of the economic vacuum created by the embargo situation and can sell its products that are otherwise unavailable to Iran. Etel Solingen therefore formulates: 'China's compliance with multilateral sanctions has been selective, reluctant, and intermittent, often relying on linguistic and behavioral contortions to justify inconsistencies. ${ }^{72}$

The transition to a new Chinese leadership, begun with the appointment of a new Politburo and Politburo Standing Committee in November 2012, seems to underline the tendency of an assertive Chinese foreign policy that is outspoken about its interests and unwilling to join or support Western policies that are seen as 'neo-interventionism'. ${ }^{73}$ The Eighteenth Party Congress report (of November 2012) was a case in point and stressed the concept of China's 'peaceful development', but equally warned, in quite explicit language, of the danger of 'hegemonism', 'power politics' and 'neo-interventionism'. ${ }^{74}$ This rhetoric was echoed by then party general secretary Xi Jinping in January $2013^{75}$ and sounded a note of caution against any hopes China could be brought on board for interventionist policies - a timely positioning against the backdrop of the NATO intervention in Libya, attempted UNSC resolutions on Syria and

\footnotetext{
${ }^{67}$ David Shambaugh, Modernizing China's Military: Progress, Problems and Prospects (Berkeley: University of California Press, 2002), p. 222; Jonathan Holslag, Trapped Giants: China's Troubled Military Rise (London: Routledge, 2011).

${ }^{68}$ Holslag, Trapped Giants, p. $29 f$.

${ }^{69}$ Holslag, Trapped Giants, p. $29 \mathrm{f}$.

${ }^{70}$ Jonathan Holslag makes an interesting point with reference to different structural levels of power: while the Asian security architecture (the 'superstructure of regional security') is becoming increasingly bipolar as evidenced by the carving out of spheres of influence between China and the US, there will remain a 'multipolar sub-structure in which the other powers make their independent choices about whether to balance, hedge or jump on the bandwagon'; Holslag, Trapped Giants, p. 109.

${ }^{71}$ Jacques, When China Rules the World, p. $117 \mathrm{f}$.

72 Etel Solingen, 'Ten dilemmas in nonproliferation statecraft', in Etel Solingen (ed.), Sanctions, Statecraft, and Nuclear Proliferation (Cambridge: Cambridge University Press, 2012), p. 333.

${ }^{73}$ Chatham House, 'China's new leadership: approaches to international affairs', Asia Meeting Summary, 7

March 2013, p. 5.

${ }^{74}$ Chatham House, 'China's new leadership'.

${ }^{75}$ Xi Jinping's taking over of the office of president in March 2013 marked the official transfer of power to a new Chinese leadership.
} 
sabre-rattling over Iran. With Xi Jinping leading the Central Military Commission at the same time, he holds the full institutional control over not only the Communist Party but also the military. His positioning against interventionist policies can therefore arguably be read as a sign of foreign policy continuity (and even reinforcement) of counter-hegemonic foreign policies.

One does not even have to agree with John Garver, theorizing on a scenario where a hegemonic China in East Asia together with a dominant Iran in West Asia could become 'a central element of a post-unipolar, China-centred Asia in the middle of the twenty-first century' ${ }^{76}$ to acknowledge China's Iran policy as becoming more self-confident. This will have a bearing on the future direction of the E3-China dialogue over Iran as well: as the US has much more leverage over China than the EU, and with the historic exploration of direct US-Iranian bilateral talks under the Obama and Rouhani administrations at the time of writing, it seems high time for the EU to reconsider its strategic (sanctions) approach to Iran if it wants to preserve leverage power both in China and in Iran. ${ }^{77}$ At the same time, such theorising of a political estrangement need not be overstated: China naturally has an interest in a stable Middle East. A regional destabilisation through the outbreak of an open military conflict would severely endanger and disrupt Chinese oil supplies. Not being pro-active itself, but waiting for European initiatives to de-escalate the tensions, China can conveniently follow a strategy of maintaining its market position in Iran while benefiting politically from ('free riding' on) Western diplomatic efforts. ${ }^{78}$

\section{Conclusion}

China's Iran policy is determined by factors at the level of energy politics (ensuring stable supplies for its economy), the regional level (maintaining peaceful relations with its neighbours and upholding the image of 'peaceful development') and the global level (demonstrating and portraying an awareness of the responsibilities as an influential power on the global stage, including compliance with the nuclear non-proliferation regime). And one might arguably add a 'civilizational' level of Third World solidarity and opposition to US hegemony underlying China's approach to Iran. The latter observation only seems to have been reconfirmed with the power transition taking place under Xi Jinping, although this should not be confused with an ideological stylisation of an 'Eastern bloc' policy as pursued by the Ahmadinejad administration. $^{79}$

The Chinese government has an interest in good economic relations and in securing its energy supplies from Iran's huge oil and gas fields, as evidenced most prominently by a 25 -year contract concluded in 2004 between Iran and Zhuhai Zhenrong Corporation to import 110 million metric tons of LNG from the Iranian North Pars and Yadavaran oilfields. Iran, in turn,

\footnotetext{
${ }^{76}$ John Garver, China and Iran: Ancient Partners in a Post-imperial World (Seattle: University of Washington Press, 2006), p. 295.

${ }^{77}$ Former IAEA Secretary General Mohamed ElBaradei also concisely criticised the proposed EU 'dual-track approach' of offering incentives in exchange for Iranian concessions while threatening sanctions at the same time as a 'fallacy ... from a cultural perspective' and as being 'like going into a souk and offering the proprietor a fair sum for the desired merchandise but also threatening to burn down the shop if he didn't accept'; ElBaradei, The Age of Deception, p. 196.

${ }^{78}$ EEAS official, author's interview, 13 March 2013.

${ }^{79}$ Seyed Hossein Mousavian, The Iranian Nuclear Crisis: A Memoir (Washington: Carnegie Endowment for International Peace, 2012), pp. 84, 141.
} 
imports some of its refined petrol from China owing to its own limited refining capacities. Iranian-Chinese bilateral trade is intensive, with Iran also being an important buyer of Chinese military exports. ${ }^{80}$ China's trade relations with Iran explain why mounting tensions surrounding the Iranian nuclear programme are not in China's interest in a stable Middle East. At the same time, China is careful not to spoil its relations with the US or to provoke perceptions that run counter to that of a Chinese 'peaceful development' by openly contravening existing sanctions lists; and, like Russia, did not hinder the latest UNSC resolution 1929, trying to balance a pragmatic-commercial approach to business in Iran and mollifying Western security concerns related to the Iranian nuclear programme. Despite a certain rhetoric coming from Beijing in this regard, Chinese investment figures in Iran need to be handled with caution, as the Chinese politico-economic balancing act strategically freezes certain economic projects in the planning phase.

In its official diplomacy, China continuously underlines Iran's legitimate right to nuclear technology for civilian usage as well as the need to respect Iranian sovereignty, criticising any over-hasty infringements stemming from non-proven proliferation concerns. With the US and EU administrations pursuing a tough public diplomacy line towards Iran over its controversial nuclear programme, China does not necessarily share the same security political prioritisations and is gradually becoming more outspoken about this fact. In particular, the EU oil embargo in July 2012 and the most recent EU sanctions round in October 2012 have underlined a growing rift between the EU's and China's stance towards Iran when it comes to an understanding of the use of sanctions. As the EU does not have the same political significance for China as does the US, the EU's leverage power is limited. Irrespective of the impact of EU sanctions on the Iranian economy, it should have become obvious from the above analysis that a tough EU stance on Iran does not motivate China to follow suit. And even though US unilateral sanctions against third parties' involvement with Iran are a thorn in the flesh of Chinese companies and Chinese business interests in Iran, their enforcement has a certain 'disciplinary effect', as illustrated by China's qualification for the US oil trade 'waivers' in case of compliance. An EU embargo against Iranian crude oil, however, is no inducement for China to cut back on its economic activities with Iran. And even though the EU's policy of not insuring Chinese oil tanker shipments is an annoyance to Beijing, the latter's decision to insure its vessels otherwise testifies to China's relative indifference to the EU's punitive Iran stance.

After largely unsuccessful rounds of negotiations in Istanbul, Bagdad and Moscow in 2012, the one-on-one talks in December 2012 between the EU High Representative Catherine Ashton and the Iranian chief nuclear negotiator Saeed Jalili have initiated a renewed dialogue round that was taken up again after the Iranian presidential elections in June 2013. The dynamics taking place after Rouhani's election as Iran's new president and the Iranian diplomatic outreach in the fall of 2013 constitutes a new chance for constructive dialogues at the time of writing. Even

\footnotetext{
${ }^{80}$ Cf. Dan Blumenthal, 'Providing arms: China and the Middle East', Middle East Quarterly, Vol. 12 (2005), pp. 11-19; Manochehr Dorraj and Carrier Currier, 'In arms we trust: strategic and economic factors motivating China-Iran relations', The Chinese Journal of Political Science, Vol. 15 (2010), pp. 49-69; Bates Gill, 'Chinese arms exports to Iran', Middle East Review of International Affairs, Vol. 2 (1998), pp. 55-70; Dennis V. Hickey, 'New directions in China's arms for export policy: an analysis of China's military ties with Iran', Asian Affairs: An American Review, Vol. 17 (1990), pp. 15-29.
} 
though a concrete roadmap for a solution to the decade-old intricate nuclear stalemate will take much more time, it has widely been acknowledged that the P5+1 talks in Geneva in October and November 2013 have been much-needed confidence-building exercises as an important basis for further substantive talks. A long-term solution, as this paper has attempted to show, can only be found with all stakeholders involved, including all UNSC veto powers. As the sanctions issue and China's foreign policy towards the Iran issue aptly demonstrate, this can only be achieved through political dialogue and negotiations - however tiresome the repetition of this formula has become. A single-focused unilateral sanctions track not only alienates the Iranian dialogue partners, it also decreases the chances of finding common policy positions visà-vis the Iranians between the 'Western' and the 'non-Western' camps within the P5+1. Given the institutionalised nature of the sanctions regime, sanctions relief as a necessary confidencebuilding measure on the part of the West is not an easy task. This is especially true of Congressional hurdles with a view to US unilateral sanctions. ${ }^{81}$ Starting by rolling back unilateral EU sanctions such as the Iran oil embargo would not only be an important gesture to Iran on the part of the West, ${ }^{82}$ it would also be an attempt for the EU to regain lost credibility in emancipating itself from a punitive track that has become self-perpetuating and has rendered the initially stated 'engagement' approach an empty phrase at best.

University of Kent

mp442@kent.ac.uk

\footnotetext{
${ }^{81}$ Lohmann, 'Unilaterale US-Sanktionen gegen Iran'.

${ }^{82}$ This would involve a politically difficult departure from the principle of consensus in the E3+3 mechanism.
} 